\title{
Chapter 8 \\ Corruption Gone Wild: Transnational Criminal Law and the International Trade in Endangered Species
}

\author{
Radha Ivory
}

\begin{abstract}
The chapter sketches how the topics of corruption and endangered animal trafficking have been intertwined in hard and soft international law, including by United Nations Security Council resolutions. The legal documents depict corruption as enabling the illegal wildlife trade, and, concomitantly, portray the illegal wildlife trade as prompting official corruption. Ivory cautions against linking the two legal frameworks and reform agendas. Notably, the linkage implies that animal products are legitimate commodities when traded in an uncorrupted global market. The linkage may also focus too much attention on the criminal individuals who contribute to animal extinction, rather than on the large-scale environmental changes caused by industrialization and urbanization. Finally, the twinning of the two discourses could amplify the demonization of low-level bribery and poaching that are typically associated with the Global South. A combined anti-corruption/wildlife trafficking debate may distract from the opportunities for illicit investment and excessive consumption in the Global North, which enable and drive the crimes.
\end{abstract}

\section{Introduction}

If violence is an obvious modus operandi of the illegal wildlife trade, corruption is an increasingly visible other. At least since the mid-2000s, states have softly acknowledged connections between the transnational crimes and called on each

\footnotetext{
Revised version of the original published article "Corruption Gone Wild: Transnational Criminal Law and the International Trade in Endangered Species" by Radha Ivory, American Journal of International Law Unbound, Volume 111, 2017, pp. 413-418. The original article was published as an Open Access article, distributed under the terms of the Creative Commons Attribution licence (http://creativecommons.org/licenses/by/4.0/). The revisions were finalised on 1 June 2018.
}

R. Ivory $(\bowtie)$

University of Queensland, TC Beirne School of Law, St Lucia, QLD, Australia

e-mail: r.ivory@law.uq.edu.au

(C) The Author(s) 2020

A. Peters (ed.), Studies in Global Animal Law, Beiträge zum ausländischen

öffentlichen Recht und Völkerrecht 290,

https://doi.org/10.1007/978-3-662-60756-5_8 
other to uphold conventions that support the respective fields of cooperation. In recent years, the Security Council has hardened the doctrinal links in resolutions on particular 'security' situations. These constructions, in turn, resonate with research publications by academics, international organisations, and non-state actors. Examining this emerging orthodoxy, this chapter briefly sketches how, and with what effect, the problems of corruption and endangered animal trafficking have been linked in international law. It first compares and contrasts the 'hard law' legal frameworks on corruption and on animal trafficking. After that, it illustrates how those two regimes have been related in international reports, non-binding international instruments, and UN Security Council Resolutions. Finally, drawing on critical literatures in international law and criminology, it cautions against an automatic merger of these agendas for global law enforcement and reform. Like other transnational criminal laws, the anti-corruption treaties have practical limitations, ideological biases, and potentials for unintended consequences. These features qualify their utility as 'tools' in the fight for animal welfare. They may also mask the ways in which efforts to prevent and suppress wildlife trafficking are both anthropocentric and sources of human insecurity.

\section{Prohibiting Corruption and Wildlife Trafficking Through International Law}

Illegal wildlife trafficking and corruption are dealt with under different international agreements with different logics of regulation. The key global Convention on International Trade in Endangered Species of Wild Fauna and Flora (CITES) ${ }^{1}$ aims to regulate the transactions in endangered animals and plants by establishing an international licensing system. ${ }^{2}$ The CITES appends three lists of variously at-risk species. Before listed animals or their parts or products ('specimens') can be lawfully traded, states must demand certain documentation. ${ }^{3}$ Those documents may only be issued when approvals have been obtained from national 'Scientific' or 'Management Authorities'. ${ }^{4}$ States have discretion as to how they enforce the CITES system within domestic law; however, they must penalise the illegal trade and/or possession of listed specimens and enable the confiscation or return of such specimens to export countries. ${ }^{5}$ By contrast, the international regime against corruption contains more

\footnotetext{
${ }^{1}$ Convention on International Trade in Endangered Species of Wild Fauna and Flora (CITES), 3 March 1973, 993 UNTS 243.

${ }^{2}$ See, generally, Bowman/ Davies/Redgwell, Lyster's International Wildlife Law 2010, 14, ch. 15. ${ }^{3}$ CITES 1973, arts. III-IV.

${ }^{4}$ Ibid. and art. IX.

${ }^{5}$ CITES 1973, art. VIII(1).
} 
than a dozen binding instruments addressed to offences like bribery, embezzlement, and money laundering. ${ }^{6}$ These anti-corruption treaties commit their state parties to criminalising abuses of power or trust for private gain, along with activities that enable offenders to avoid prosecution and/or enjoy ill-gotten wealth. ${ }^{7}$ States must meet these transgressions with criminal penalties and take steps to ensure that persons can be deprived of illicit wealth, as a rule. Assuming that assets, offenders, and evidence may be located in different states, the treaties commit state parties to assisting each other in criminal matters. ${ }^{8}$ In this way, the anti-corruption treaties are examples of 'suppression conventions', which are said to constitute the hard core of a 'Transnational Criminal Law'.

\section{Linking International Norms Against Corruption and Wildlife Trafficking}

The treaties on wildlife trafficking and corruption thus use different approaches to controlling acquisitive crimes of globalisation. Textually they are connected through oblique references to sustainable (economic) development in some anti-corruption standards. ${ }^{10}$ Links between wildlife trafficking and corruption are drawn rather in research publications, soft laws, and Security Council resolutions, which I discuss below. Taken together, these documents paint a picture of corruption as enabling the illegal wildlife trade and the illegal wildlife trade as prompting official corruption. Both types of crime are tied to inequality between countries and instability within them.

\subsection{Research Publications}

Academics, international and non-governmental organisations have presented corruption and the trafficking of wild animal and plant specimens as functionally

\footnotetext{
${ }^{6}$ See, esp., Convention on Combating Bribery of Foreign Public Officials in International Business Transactions, 17 December 1997, 37 ILM (1998), 1 (OECD Convention); United Nations Convention against Transnational Organized Crime, 15 November 2000, 2225 UNTS 209 (UNTOC); United Nations Conventions against Corruption, 31 October 2003, 2349 UNTS 41 (UNCAC). See, further, Ivory, Human Rights of Bad Guys 2014, 1-3, 16 (table 2.1).

${ }^{7}$ Ivory, Human Rights of Bad Guys 2014, 12-22.

${ }^{8}$ See, generally, Ivory, Human Rights of Bad Guys 2014, ch. 4.

${ }^{9}$ See, esp., Boister, “'Transnational Criminal Law”?' 2003, 953-976.

${ }^{10}$ See, esp., UNCAC 2003, preamble; UNTOC 2000, art. 30(1); OECD, Recommendation of the Council for Further Combating Bribery of Foreign Public Officials in International Business Transactions, C(2009)159/REV1/FINAL, 26 November 2009, preamble. See also UN General Assembly, Transforming Our World: The 2030 Agenda for Sustainable Development, 25 September 2015, A/RES/70/1, Annex, Goals 15.7 and 16.5.
} 
interconnected. ${ }^{11}$ The relationship is complex, not least at the micro-level of particular crime situations. ${ }^{12}$ Generalising here about the macro-level, the CITES emerges as a tool for animal protection but also a source of opportunities and incentives for bribery. ${ }^{13}$ On the one hand, wildlife control regimes give public officials monopoly rights to authorise or otherwise enable lucrative transactions. ${ }^{14}$ Officials may have broad (and/or weakly supervised) discretions to deploy their powers. ${ }^{15}$ Other (more senior) persons may resist implementing the relevant laws or making reforms that would help combat corruption or improve the operation of protections for animals. ${ }^{16}$ They may profit as illicit 'producers' or 'traders' in their own right or as beneficiaries of bribes paid or raised by others in public service. ${ }^{17}$ On the other hand, traffickers have economic reasons to offer illegal premiums to authorities or to seek to have permission processes expedited, conditions eased, and/or paperwork falsified. Alternatively, officials may be bribed to ignore illegal operations and/or to warn traffickers about planned interception efforts or raids. ${ }^{18}$ Some traffickers could also operate with, or as, organised criminal groups. ${ }^{19}$ Finally, corruption and wildlife trafficking are seen to enable, and be enabled by, the same global disparities in

\footnotetext{
${ }^{11}$ Wyatt/Cao, 'Corruption and Wildlife' 2015, 7, available at: www.u4.no/publications/corruptionand-wildlife-trafficking/downloadasset/3832. See, e.g., Environmental Investigation Agency (EIA), 'Time for Action: End the Criminality and Corruption Fuelling Wildlife Crime' (2016), available at: www.eia-international.org; UN Office on Drugs and Crime (UNODC), 'World Wildlife Crime Report: Trafficking in Protected Species' (2016), available at: https://www.unodc.org/unodc/en/ data-and-analysis/wildlife.html; Moreto/Brunson/Braga, 'Law Enforcement Ranger Wrongdoing' 2015, 359-380; Smith/Walpole, 'Should Conservationists Pay More Attention to Corruption?' 2005, 251-256; World Wildlife Fund (WWF)/TRAFFIC Wildlife Crime Initiative, 'Strategies for Fighting Corruption in Wildlife Conservation: A Primer' (2015), available at: wwf.panda.org/? 257350/Strategies-for-fighting-corruption-in-wildlife-conservation; van Uhm/Moreto, 'Corruption within the Wildlife Trade' 2017; Wyatt, Wildlife Trafficking 2013, 52-53.

${ }^{12}$ See, e.g., Moreto/Brunson/Braga, 'Law Enforcement Ranger Wrongdoing' 2015, 367-376; van Uhm/Moreto, 'Corruption within the Wildlife Trade' 2017, 8-16. See also UNODC, 'World Wildlife Crime Report' 2015, 23-24.

${ }^{13}$ See generally UNODC, 'World Wildlife Crime Report' 2015, 19, 23-24.

${ }^{14}$ Ibid., 97.

${ }^{15}$ Moreto/Brunson/Braga, 'Law Enforcement Ranger Wrongdoing' 2015, 377; WWF/TRAFFIC, 'Strategies for Fighting Corruption' 2015, 8-13; Wyatt/Cao, 'Corruption and Wildlife' 2015, 8-14. ${ }^{16}$ WWF/TRAFFIC, 'Strategies for Fighting Corruption' 2015, 13-14; Wyatt, Wildlife Trafficking 2013; Wyatt/Cao, 'Corruption and Wildlife' 2015, 12.

${ }^{17}$ For an example from the illegal timber trade, albeit not with reference to the CITES, see Global Witness, 'Cambodia's Family Trees: Illegal Logging and the Stripping of Public Assets by Cambodia's Elite', 2007, available at: https://www.globalwitness.org/en/reports/cambodias-fam ily-trees, $10-11$.

${ }^{18}$ WWF/TRAFFIC, 'Strategies for Fighting Corruption' 2015, 10-15; Wyatt/Cao, 'Corruption and Wildlife' 2015, 9-10.

${ }^{19}$ Ibid., 6. See also Ayling, 'What Sustains Wildlife Crime?' 2013, 68.
} 
'development' and 'governance'. ${ }^{20}$ Hence, addressing one problem may contribute to efforts to ameliorate the other.

\subsection{Soft Law Statements}

States have called on each other to address the problems of wildlife-related corruption through non-binding international decisions. At least since 2007, bodies within the UN system have called on countries to use the UN Conventions against Corruption and Organized Crime (UNCAC and UNTOC) to combat animal trafficking. ${ }^{21}$ Moreover, in 2010, the CITES Secretariat formed an International Consortium on Combating Wildlife Crime that includes the UN Office on Drugs and Crime and the World $\mathrm{Bank}^{22}$ : the latter organisations are intimately engaged with worldwide anticorruption activity. Three years later, in December 2013, the General Assembly '[e] mphasis[ed] that coordinated action is critical to eliminate corruption and disrupt the illicit networks that drive and enable trafficking in wildlife, timber and timber products (...)'. ${ }^{23}$ Less than 2 years after that, it resolved, without a vote, to call on Member States to 'prohibit, prevent and counter any form of corruption that facilitates illicit trafficking in wildlife and wildlife products', as well as to join and implement the UNCAC and UNTOC. ${ }^{24}$ Similar sentiments have been expressed in decisions of the CITES' Conference of the Parties, ${ }^{25}$ the UN's Economic and Social Council, ${ }^{26}$ and the Environment Assembly of the UN Environment Programme, ${ }^{27}$ as

\footnotetext{
${ }^{20}$ See generally EIA, 'Time for Action' 2016, 16; Smith/Walpole, 'More Attention to Corruption' 2005, 251-252; van Uhm/Moreto, 'Corruption within the Wildlife Trade' 2017, 2-4; Wyatt/Cao, 'Corruption and Wildlife' 2015, 7-9. Cf UNODC, 'World Wildlife Crime Report' 2015, 19.

${ }^{21}$ United Nations, Commission on Crime Prevention and Criminal Justice, Resolution 16/1, International Cooperation in Preventing and Combating Illicit International Trafficking in Forest Products, including Timber, Wildlife and other Forest Biological Resources, E/2007/30/Rev.1 \& E/CN.15/2007/17/Rev.1, 23-27 April 2007.

${ }^{22}$ CITES Secretariat, 'Projects and Initiatives: The International Consortium on Combating Wildlife Crime' (website), available at: https://www.cites.org/eng/prog/iccwc.php.

${ }^{23}$ United Nations, General Assembly, Resolution 68/193, Strengthening the United Nations Crime Prevention and Criminal Justice Programme, in particular its Technical Cooperation Capacity, A/RES/68/193, 18 December 2013, preamble.

${ }^{24}$ United Nations, General Assembly, Resolution 69/314, Tackling Illicit Trafficking in Wildlife, A/RES/69/314, 30 July 2015, paras. 9-11. See also United Nations, General Assembly, Tackling Illicit Trafficking in Wildlife: Report of the Secretary-General, A/70/951, 16 June 2016, para. 56; United Nations, General Assembly, Resolution 71/326, Tackling Illicit Trafficking in Wildlife, 11 September 2017, A/RES/71/326, esp. paras. 8, 19-20.

${ }^{25}$ CITES, Seventeenth Meeting of the Conference of the Parties, Resolution 17.6, Prohibiting, Preventing, Detecting and Countering Corruption, which Facilitates Activities Conducted in Violation of the Convention, Conf. 17.6, 24 September-4 October 2016.

${ }^{26}$ United Nations, Economic and Social Council, Resolution 2013/40, Crime Prevention and Criminal Justice Responses to Illicit Trafficking in Protected Species of Wild Fauna and Flora, E/RES/2013/40, 25 July 2013.

${ }^{27}$ United Nations, Report of the United Nations Environment Assembly of the United Nations Environment Programme, 23-27 June 2014, A/69/25, 20-23, Resolution 1/3, para. 2(g). See also
} 
well as at high-level meetings of international leaders. ${ }^{28}$ For example, the G20 annexed 'High Level Principles on Combatting Corruption Related to Illegal Trade in Wildlife and Wildlife Products' to their 2017 Hamburg Declaration. ${ }^{29}$ Later that year, the CITES' Secretary General addressed the UNCAC state parties in the opening session of their conference. ${ }^{30}$

\subsection{Security Council Resolutions}

In parallel, the UN Security Council has been reconstructing wildlife trafficking as a danger to the peace. In a significant development, ${ }^{31}$ it has hardened the doctrinal connections between armed conflict, illegal trade in animal products, and other forms of transnational criminality. Thus, resolutions on the Central Africa Republic (CAR) and the Democratic Republic of Congo (DRC) attribute violence there, in part, to the ability of groups to fund their activities through the illegal sale of natural resources. ${ }^{32}$ Travel bans and asset freezes are targeted at individuals and entities who, amongst other things, support the trade in elephant tusks. ${ }^{33}$ In addition, there is an exception to an arms embargo to 'defend against poaching [and] smuggling of ivory (...)' from CAR, ${ }^{34}$ and mention of the smuggling of Congolese ivory in the same breath as 'the importance of neutralising all armed groups' in the DRC. ${ }^{35}$ Outside the scope of the CITES but still with relevance to animal products and biodiversity, council resolutions signal that illegal fishing and corruption are barriers

United Nations, United Nations Environment Assembly of the United Nations Environment Programme, Resolution 2/14, Illegal Trade in Wildlife and Wildlife Products, 23-27 May 2016, para. 1(b).

${ }^{28}$ London Conference on the Illegal Wildlife Trade, Declaration, 12-13 February 2014, available at: https://www.gov.uk/government/topical-events/illegal-wildlife-trade-2014, arts. IX-XII; East Asia Summit Declaration on Combating Wildlife Trafficking, 13 November 2014, available at: https:// cites.org/eng/east_asia_summit, art. 14.

${ }^{29}$ G20, Leaders' Declaration: Shaping an Interconnected World, Annex: G20 High Level Principles on Combatting Corruption Related to Illegal Trade in Wildlife and Wildlife Products, 8 July 2017, available at: https://www.g20germany.de/Webs/G20/EN/G20/Summit_documents/summit_docu ments_node.html.

${ }^{30}$ United Nations, Office on Drugs and Crime, 'Press Release: Links between Corruption and Wildlife Crime Highlighted at UN Anti-Corruption Conference', 6 November 2017, available at: https://www.unodc.org/unodc/en/press/allpress.html?ref $=\mathrm{fp}$.

${ }^{31}$ Peters, 'Novel Practice of the Security Council' 2014.

${ }^{32}$ See, e.g., United Nations, Security Council, Resolution 2339, S/RES/2339 (2017), 27 January 2017, preamble (on CAR); United Nations, Security Council, Resolution 2293, S/RES/2293 (2016), 23 June 2016, preamble (on DRC).

${ }^{33}$ See, e.g., UNSC, Resolution 2339 (2017), para. 17(e); UNSC, Resolution 2293 (2016), para. 7(g).

${ }^{34}$ UNSC, Resolution 2339 (2017), para. 1(f).

${ }^{35}$ UNSC, Resolution 2293 (2016), preamble. 
to the consolidation of peace and sovereignty in Somalia ${ }^{36}$ and Guinea-Bissau, ${ }^{37}$ along with drug trafficking, money laundering, and piracy.

\section{Contesting the Connection Between the Anti-corruption and Anti-wildlife Trafficking Agendas}

Hence, there would seem to be an emerging international consensus that wildlife trafficking, transnational organised crime, and corruption must be addressed together and that their respective regimes, whilst distinct, are complementary. Yet, just as some have questioned invoking anti-corruption law to support the cause of human rights (and vice versa), so I see three reasons to pause before merging the international anti-corruption and pro-wildlife agendas wholesale. My grounds are pragmatic, normative, and epistemological. ${ }^{38}$

\subsection{Effectiveness}

First, the enforcement of international anti-corruption law is not a silver bullet for difficulties in enforcing international laws that aim to control the trade in endangered species. In fact, transnational measures against economic crime face their own critiques about effectiveness. There are initial problems with determining whether-and, if so, why-states comply with duties to implement international anti-corruption treaties. If they do so out of self-interest or peer pressure, the treaties might not be such a successful ethical check on power-political calculations. ${ }^{39}$ Further, it is difficult to measure and prove the effectiveness of international crime control measures on individual decisions to break the law. Perhaps for this reason, inter-governmental assessments of anti-money laundering controls have tended to focus on the 'volume of activities undertaken by competent authorities', even though these measures say little 'about the real impact of such actions on the criminal problem itself'. ${ }^{40}$ Finally, even high-income countries would seem reluctant to prosecute foreign bribe payers and/or confiscate and return illicit wealth laundered

\footnotetext{
${ }^{36}$ See, e.g., United Nations, Security Council, Resolution 2125, S/RES/2125 (2013), 18 November 2013, preamble; United Nations, Security Council, Resolution 2317, S/RES/2317 (2016), 10 November 2016, preamble, paras. 17 and 21; United Nations, Security Council, Resolution 2383, S/RES/2383 (2017), 7 November 2017, preamble, para. 2; United Nations, Security Council, Resolution 2385, S/RES/2385 (2017), 14 November 2017, preamble, para. 20.

${ }^{37}$ See, e.g., United Nations, Security Council, Resolution 2343, S/RES/2343 (2017), 23 February 2017, preamble; United Nations, Security Council, Resolution 2404, Resolution 2404 (2018), 28 February 2018, preamble, para. 20.

${ }^{38}$ See, further, Ivory, 'Asset Recovery in Four Dimensions' 2017, 176-210.

${ }^{39}$ See Sharman, The Despot's Guide to Wealth Management 2017, 13-14.

${ }^{40}$ Vettori, 'Evaluating Anti-Money Laundering Policies 2013, 474-485. See also Halliday/Levi/ Reuter (for the Centre on Law \& Globalization), 'Global Surveillance of Dirty Money’ 2014.
} 
through their financial centres. ${ }^{41}$ This may weaken any general deterrent effect of international anti-corruption measures insofar as it sends an inconsistent message to individuals (and corporations) about the likelihood that wrongdoing will be detected, investigated, and punished.

\subsection{Human Rights}

Second, increasing compliance with international law is not an absolute good for governance-it also generates costs. The international treaties against corruption commit states to standardising their domestic responses to certain types of behaviours and to cooperating with each other in judicial and administrative matters. Both Gless and Boister discuss the risks to defendants when states pool their ius puniendi. ${ }^{42}$ Focusing on the international campaign for asset recovery, I have shown elsewhere that states' efforts to cooperate in confiscation matters may raise issues under rights to fair trials and property. International judges permit such interferences as a means of realising important law enforcement objectives; however, they insist on the conditions of lawfulness and proportionality. ${ }^{43}$ In the wildlife protection context, human rights considerations have a communitarian dimension. Indigenous and tribal peoples have collective rights to natural resources, including when that property is contained within nature reserves. ${ }^{44}$ In Kaliña and Lokono Peoples v. Suriname, the Inter-American Court of Human Rights found environmental protection and self-determination to be compatible policy objectives. ${ }^{45}$ But the court there referred to international instruments that recognise both indigenous peoples' special interests in land and the global collective interest in biodiversity. ${ }^{46}$ The CITES makes only general references to natural resource sovereignty and provides no traditional use exception for animal products: it is less amenable to harmonious interpretation. Hence, there is greater potential for conflict between

\footnotetext{
${ }^{41}$ Heimann/Foldes/Coles (for Transparency International), 'Exporting Corruption' 2015; Gray et al. (for the International Bank for Reconstruction and Development/World Bank/Organisation for Economic Co-operation and Development), 'Few and Far' 2014.

${ }^{42}$ Boister, 'Human Rights Protections in the Suppression Conventions' 2002, 199-227; Gless, 'Bird's-Eye View and Worm's Eye View: Towards a Defendant-Based Approach in Transnational Criminal Law' 2015, 117-140.

${ }^{43}$ Ivory, Human Rights of Bad Guys 2014, ch. 5 and 6.

${ }^{44}$ See, e.g., Centre for Minority Rights Development (Kenya) and Minority Rights Group International on behalf of Endorois Welfare Council v. Kenya, African Commission of Human and Peoples' Rights, 4 February 2010, Communication No. 276/03; The Case of the Kaliña and Lokono Peoples v. Suriname, Judgement of 25 November 2015 (Merits, Reparations, and Costs), Series C No. 309. See also African Commission of Human and Peoples' Rights v. Kenya, African Court on Human and People's Rights, 26 May 2017, Application No. 006/2012.

${ }^{45}$ Kaliña and Lokono Peoples v. Suriname 2015, paras. 173, 181.

${ }^{46}$ Ibid., paras. $174-180$.
} 
collective rights that benefit indigenous and tribal peoples and norms that protect wildlife in international law.

\subsection{Politics}

Third, measures to prevent animal trafficking and to control corruption may serve particular political agendas. This is not simply a point about Western states and non-state actors advocating regimes that prohibit transnational crime. ${ }^{47}$ Rather, the anti-corruption and anti-wildlife trafficking orders may reflect, and help maintain, certain ideas about acceptable power relations between humans and animals, peoples and states. To begin, the linking of anti-corruption and wildlife trafficking discourses may potentially subjugate animals, since it suggests that animal products are legitimate commodities when traded in uncorrupted global markets. Likewise, the merger of the anti-corruption and wildlife trafficking discourses may be taken to signal that criminal individuals have caused mass animal endangerment, rather than large-scale environmental changes post-industrialisation. ${ }^{48}$ Similarly, critical anti-corruptionists (and Third World scholars of international law) may see a postcolonial downside to a twinned agenda. The discourses of anti-corruption and anti-wildlife trafficking could each serve to demonise forms of conduct, like low-level bribery and poaching, which are perceived to be more prevalent in the Global South. They may together distract from the possibilities for illicit investment and patterns of excessive consumption in the Global North, which enable and drive the crimes. ${ }^{49}$ Finally, some might take the Security Council's efforts to protect animals to be an example of the securitisation of global environmental governance or the militarisation of transnational organised crime controls. ${ }^{50} \mathrm{~A}$ 'fear-based approach' to deterrence may be counter-productive if it constructs animal protection as an illegitimate goal and a point of community resistance. ${ }^{51}$ Further, attempts by national authorities to establish and protect animal habitats have been described as 'green grabbing', or the expropriation of spaceparticularly from marginalised peoples - for environmental reasons. These strategies may have a neoliberal economic dimension, if private entrepreneurs operate the parks that are supposed to protect animals. ${ }^{52}$

\footnotetext{
${ }^{47}$ See, e.g., Adam, Elephant Treaties 2014; Andreas/Nadelmann, Policing the Globe 2006, 46-50. ${ }^{48}$ Pires/Moreto, 'The Illegal Wildlife' 2016.

${ }^{49}$ Brown/Cloke, 'The Critical Business of Corruption' 2006, 238; Brown/Cloke, 'Critical Perspectives on Corruption' 2011, 118.

${ }^{50}$ See generally Kelly/Ybarra, 'Introduction to themed issue: "Green security in protected areas", 2016, 171-175; Humphreys/Smith, 'Militarised Responses to the Illegal Wildlife Trade' 2018, $25-42$.

${ }^{51}$ Moreto/Gau, 'Deterrence, Legitimacy, and Wildlife Crime in Protected Area' 2017, 51.

${ }^{52}$ Massé/Lunstrum, 'Accumulation by Securitization' 2016, 227-237.
} 


\section{Conclusion}

There is thus a need for caution in accepting calls for more and stronger measures to combat wildlife trafficking and corruption. Bribery is seen to enable wildlife trafficking, and wildlife trafficking is seen be one of those illicit industries that motivates active and passive corruption. The two sets of offences can be addressed simultaneously, it is said, and perhaps alongside other efforts to ensure international peace, security, and transnational crime control. However, the effectiveness of economic crime control regimes may be hard to determine and their more draconian mechanisms may generate tensions with individual civil and political rights. Other prospects for fragmentation become clear when special duties to protect collective interests are factored in. Further, the anti-corruption and anti-wildlife trafficking movements may as anthropocentric and/or Eurocentric, especially if they are put together. Finally, I wondered whether a securitised transnational animal law would create new forms of environmental injustice and be self-defeating. Could it fail to protect animals while justifying limits on a range of other public goods?

\section{References}

Adam, R. (2014). Elephant treaties: The Colonial legacy of the biodiversity crisis. Hanover: University Press of New England.

Andreas, P., \& Nadelmann, E. (2006). Policing the globe: Criminalization and crime control in international relations (pp. 46-50). Oxford: Oxford University Press.

Ayling, J. (2013). What sustains wildlife crime? Rhino horn trading and the resilience of criminal networks. Journal of International Wildlife Law \& Policy, 16, 57-80.

Boister, N. (2002). Human rights protections in the suppression conventions. Human Rights Law Review, 2, 199-227.

Boister, N. (2003). "Transnational Criminal Law"? European Journal of International Law, 14, 953-976.

Bowman, M., Davies, P., \& Redgwell, C. (2010). Lyster's international wildlife law (2nd ed.). Cambridge: Cambridge University Press.

Brown, E., \& Cloke, J. (2006). The critical business of corruption. Critical Perspectives on International Business, 2, 275-298.

Brown, E., \& Cloke, J. (2011). Critical perspectives on corruption: An overview. Critical Perspectives on International Business, 7, 116-124.

Gless, S. (2015). Bird's-eye view and worm's eye view: Towards a defendant-based approach in transnational criminal law. Transnational Legal Theory, 6, 117-140.

Gray, L., Hansen, K., Recica-Kirkbride, P., \& Mills, L. (2014). (for the International Bank for Reconstruction and Development/World Bank/Organisation for Economic Co-operation and Development), 'Few and Far: The Hard Facts on Stolen Asset Recovery', available at: http:// www.oecd.org/dac/accountable-effective-institutions/Hard\%20Facts\%20Stolen\%20Asset\% 20Recovery.pdf.

Halliday, T., Levi, M., \& Reuter, P. (2014). (for the Centre on Law \& Globalization), 'Global surveillance of dirty money: Assessing assessments of regimes to control money laundering and combat the financing of terrorism', available at: http://www.americanbarfoundation.org/publica tions $/ 752$. 
Heimann, F., Foldes, A., \& Coles, S. (2015). (for Transparency International), 'Exporting corruption: Progress report 2015: Assessing enforcement of the OECD convention on combatting foreign bribery', available at: http://www.transparency.org/exporting_corruption.

Humphreys, J., \& Smith, M. L. R. (2018). Militarised responses to the illegal wildlife trade. In T. Reitano, S. Jesperson, \& L. B. R.-B. de Lugo (Eds.), Militarised responses to transnational organised crime (pp. 25-42). Cham: Palgrave Macmillan.

Ivory, R. (2014). Corruption, asset recovery, and the prevention of property in public international law: The human rights of bad guys. Cambridge: Cambridge University Press.

Ivory, R. (2017). Asset recovery in four dimensions: Returning wealth to victim countries as a challenge for global governance. In K. Ligeti \& M. Simonato (Eds.), Chasing criminal money: Challenges and perspectives on asset recovery in the EU (pp. 176-210). Oxford: Hart/ Bloomsbury.

Kelly, A., \& Ybarra, M. (2016). Introduction to themed issue: "Green security in protected areas". Geoforum, 69, 171-175.

Massé, F., \& Lunstrum, E. (2016). Accumulation by securitization: Commercial poaching, neoliberal conservation, and the creation of new wildlife frontiers. Geoforum, 69, 227-237.

Moreto, W., \& Gau, J. (2017). Deterrence, legitimacy, and wildlife crime in protected areas. In M. Gore (Ed.), Conservation criminology (pp. 45-58). Chichester: John Wiley \& Sons.

Moreto, W., Brunson, R., \& Braga, A. (2015). "Such misconducts don't make a good ranger": Examining law enforcement ranger wrongdoing in Uganda. British Journal of Criminology, 55, 359-380.

Peters, A. (2014). Novel practice of the Security Council: Wildlife poaching and trafficking as a threat to the peace, EJILTalk!, available at: https://www.ejiltalk.org/novel-practice-of-the-secu rity-council-wildlife-poaching-and-trafficking-as-a-threat-to-the-peace.

Pires, S., \& Moreto, W. (2016). The illegal wildlife trade. In Oxford Handbooks Online, available at: http://www.oxfordhandbooks.com/view/10.1093/oxfordhb/9780199935383.001.0001/ oxfordhb-9780199935383-e-161?print=pdf.

Sharman, J. (2017). The despot's guide to wealth management: On the international campaign against grand corruption (pp. 13-14). Ithaca: Cornell University Press.

Smith, R., \& Walpole, M. (2005). Should conservationists pay more attention to corruption? Oryx, $39,251-256$.

van Uhm, D., \& Moreto, W. D. (2017). Corruption within the illegal wildlife trade: A symbiotic and antithetical enterprise. The British Journal of Criminology, 58(4), 864-885, available at: https:// doi.org/10.1093/bjc/azx032. (advanced publication).

Vettori, B. (2013). Evaluating anti-money laundering policies: Where are we? In B. Unger \& D. van der Linde (Eds.), Research handbook on money laundering (pp. 474-485). Cheltenham: Edward Elgar.

Wyatt, T. (2013). Wildlife trafficking: A deconstruction of the crime, the victims and the offenders. London: Palgrave Macmillan.

Wyatt, T., \& Cao, A. N. (2015). Corruption and wildlife trafficking, U4 Issue, 11, available at: www.u4.no/publications/corruption-and-wildlife-trafficking/downloadasset/3832.

Radha Ivory (Dr iur) is a Senior Lecturer in Law at the University of Queensland, Australia (UQ). She teaches company law and researches problems at the intersection of criminal law, public international law, and corporate governance. Her monograph, Corruption, Asset Recovery, and the Protection of Property in Public International Law: The Human Rights of Bad Guys, appeared with Cambridge University Press in 2014. Her current projects concern the emergence and scope of corporate criminal liability regimes and the transnational legal theory of corruption. Prior to joining UQ, Radha worked in the international sector and in private practice. 
Open Access This chapter is licensed under the terms of the Creative Commons Attribution 4.0 International License (http://creativecommons.org/licenses/by/4.0/), which permits use, sharing, adaptation, distribution and reproduction in any medium or format, as long as you give appropriate credit to the original author(s) and the source, provide a link to the Creative Commons licence and indicate if changes were made.

The images or other third party material in this chapter are included in the chapter's Creative Commons licence, unless indicated otherwise in a credit line to the material. If material is not included in the chapter's Creative Commons licence and your intended use is not permitted by statutory regulation or exceeds the permitted use, you will need to obtain permission directly from the copyright holder. 